УДК $130.2+140.8+281.9$

ББК $71.1+86.2+87.3$

\section{К.М. ТОВБИН}

\section{РУССКИЙ ЦЕРКОВНЫЙ РАСКОЛ И ОБРАЗОВАНИЕ «ДВУХ РОССИЙ»}

Рассмотрены ход и сущность русского церковного раскола XVII века. Исследована старообрядческая сторона последствий раскола: усвоение староверами вынужденного идейного модернизма в приложении к своему изначальному традиционализму. Превращаясь из носителей традиционного духовного движения в адептов религии, староверы выработали собственную идеологию и собственную негативную идентичность (как основные пункты религиозности современного типа). Идейно и ментально противостоя модерну, староверы использовали скрытые постмодернистские механизмы, активно запущенные в ход сегодня, при формировании стилизационной и имитационной духовности постмодерна.

Ключевые слова: модерн, православие, староверы, новообрядчество, старообрядчество, древлеправославие, раскол, контрсекуляризм, идеология, отгородительная идентичность, традиционализм, модернизм.

$\mathrm{H}$ ередко грандиозную драму русского раскола сводят к внутрицерковным неурядицам, а староверам приписывают поверхностно-культурологический характер косных сопротивленцев вхождению России в «цивилизацию». Чаще всего староверы семиотически противопоставляются обновленной государственной Церкви как патриархальные консерваторы Древней Руси. В данной статье показано наличие у старообрядцев и «никониан» общего смыслового поля, единства феноменологической напряженности, идейной и идеологической диалектической борьбы-взаимопревращения. Наступление модерна в России бросило вызов, отвечать на который
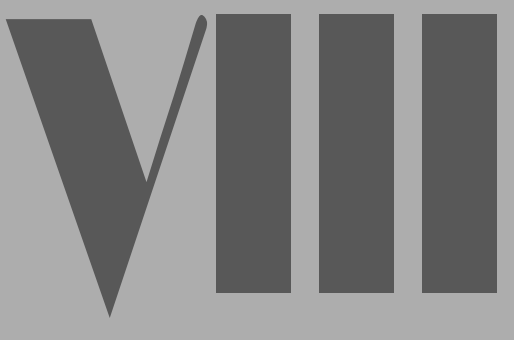

СВЯЗЬ ВРЕМЕН 
были вынуждены даже те социальные и интеллектуальные силы, которые тяготели к статусу наиболее «дремучих».

\section{Истоки}

Основным ментальным фоном, на котором происходили все духовные движения XVII века, был русский эсхатологический мессианизм, ощущение себя русскими и последним бастионом истинного православного христианства. И геноцидальные события давнего и недавнего прошлого - террор Ивана Грозного, Смута, интервенция - не только не притупили мессианское чувство, но еще более обострили его, доведя до наибольшей напряженности к XVII веку. Примечательно, что незадолго до раскола на русском языке впервые были изданы апокалиптические сочинения св. Ефрема Сирина, являющиеся важным элементом традиционной христианской эсхатологии, видящей признаки десакрализации в секуляризации. Апокалиптические предостережения св. Ефрема в сборниках «Измарагда» существенно повлияли на древнерусскую культуру [1, с. 339] и впоследствии стали важной частью старообрядческого корпуса духовного чтения.

На этом фоне произошли два ключевых события, разорвавшие ткань русской культуры и истории надвое, - «Книжная справа» патриарха Никона и Собор 1666-1667 годов. Первым событием началась семиотическая секуляризация, вторым - административная и социально-политическая (завершенная Петром I).

Сам процесс никоновской правки книг находится вне поля данного исследования - на эту тему написано достаточно исследований, исторических [2; 3] и лингвистических $[4 ; 5]$. Ради философского дискурса сто́ит отметить, прежде всего, непоследовательность проведения справы [6; 7, с. 266], отсутствие четкого плана (хотя сегодня некоторые исследователи пытаются продемонстрировать таковой [8]) и даже планомерного обоснования: «Печатайте как ни есть, только не по-старому» [9, с. 502]. Непоследовательность, сомнительность в образованности и православности справщиков, недоверие к новогреческим книгам, взятым в качестве эталонов, по этим причинам обновленцы выглядели невеждами в глазах старомосковской духовной элиты [10].

Книжная реформа была семиотической революцией, по словам Б.А. Успенского, переходом от традиционной церковнославянско-русской диглоссии - к расщепленномодернистскому двуязычию [11, с. 472].

Синтаксическая несогласованность новых текстов, затруднительность их применения в традиционном одноголосном пении, наличие вопиющих ошибок [12], которые исправлялись вплоть до XX века [13], - все это причины, по которым доступный сакральный язык превратился в узкокастовый, непригодный для легкого усвоения и цитирования и освобождающий в сознании место для некой другой лингвистической основы.

Новую основу и предложили те, с чьими именами в первую очередь ассоциируется «новообрядчество»и «антистарообрядчество» - Симеон Полоцкий, Лазарь
Баранович, Феофан Прокопович, Димитрий Ростовский, заложившие основу светской интерпретации священного (в которой переплелись чувственность барокко, богословские элементы протестантизма и католицизма, идейность европейской светской философии и поствизантийское культурно-духовное наследие). Старообрядцы же сохранили ментальную косность, бытийственную всеохватность литургического языка, древнюю традицию обучения грамотности по богослужебным книгам - по этой причине их семантическое поле не было свободно и не требовало заполнения светской культурой. Это было самодостаточное, монолитное сознание, однако совершенно непригодное для новой России, устремившейся к новым смысловым горизонтам.

Примитивизация и искусственная архаизация ритуала - одного из важнейших компонентов Традиции, которым обусловливается ее трансцендентность, преемственность и вневременность, - и превращение ритуала в «обряд», во «второстепенное» [14, с. 414], стали сильнейшим ударом по традиционному православному сознанию, сделав его измерением образованность и «просвещенность» вместо укорененности в изначальном трансцендентном смысле. Русское православное мировидение оказалось подвешенным в воздухе, лишенным основания. Древность, «заветы Отцов» превратились в пугающие фетиши, символы варварства и отсталости на идеологическом пути вечно догоняющего западничества.

Вследствие книжной справы, начавшейся в 1653 году, две группировки - традиционалисты и обновленцы столкнулись в борьбе за влияние на государственную власть, ибо только она, в духе православного византизма, могла быть верховным арбитром богословского противостояния [15, с. 82]. Более того, первые староверы как носители нерасчлененного сознания понимали, что политическое во всей полноте обусловлено духовностью, потому уклонение государя и государства «в ересь» никогда не позволит представителям альтернативной версии православия существовать в России на уровне даурских буддистов или татарских мусульман. Борьба за политическое влияние была свойственна наиболее дальновидным староверами, понимавшим, что, с точки зрения Традиции, «испорченное хуже недоделанного» [16, с. 608], потому ортодоксия не может сосуществовать с ересью.

Следующей вехой раскола был Большой Московский собор 1666-1667 годов, впоследствии названный «разбойничьим» не только староверами, но и новообрядческими исследователями [17, с. 394; 18, с. 332-333], наложивший проклятия на старые обряды и их приверженцев [19]. Нелегитимность этого Собора, инициированного иноземными архиереями, смещенными со своих кафедр (патр. Паисий Александрийский, Макарий Антиохийский [5, с. 238-252]) или находящимися под запретом в связи с уклонением в католичество (Паисий Лигарид, митр. Газский [20, с. 209; 21, с. 245-252]), была очевидной даже во время самого Собора, в связи с чем Никон отказался подчиняться прещениям со стороны этих архиереев. Эта нелегитимность заставила впоследствии, при патр. Иоаса- 
фе II, добиваться восстановления смещенных восточных патриархов через османского султана [22], дабы постфактум подтвердить в глазах верующих легитимность чисто государственнического мероприятия.

Этот Собор стал торжеством светского государственничества: были разгромлены и объявлены государственными преступниками не только староверы, но и сам Никон, создавший новый язык для нового государства [23]. Словами Никона, царь «восхитил Церковь» [21, с. 299]. Авторитет и господство безраздельно перешли в руки государя. Проект клерикализма завершился торжеством цезаропапизма [24, с. 171]. Следствиями Большого Московского собора стали:

- завершение литургической реформы Никона. «Никоновы новины» оказались символическим сопровождением качественно нового государственно-церковного соотношения. Обмирщенная знаково-ритуальная система, заимствованная из осовремененных стран (Греции, Малороссии), не только символизировала, но и осуществляла действие некой совершенно иной духовности, чуждой старорусскому благочестию;

- завершение структурной реформы Никона, уничтожившей остатки соборного начала в Русской Церкви. Вместо соборности де факто установилась система, в которой гарантом веры становился царь. По словам одного из творцов русского цезаропапизма, Паисия Лигарида, «царю свойственно судить других, но не быть судиму другими. Не таков архиерей: он и судит, и судим бывает» [21, с. 300];

- юридическое обоснование преследования староверов. Однако они преследовались не как стихийные повстанцы, продвигавшие, к примеру, Медный бунт (1662), но и не как церковные раскольники - как государственные преступники [25, с. 140].

Литургическая реформа Никона превратилась в знамя государственного администрирования (силовым путем), а обновленная Церковь - в придаток государства. Процесс этот был закончен Петром I при запрещении избрания Патриарха и учреждении Синода как государственного министерства во главе с государевым чиновником.

Староверы, для которых решения Собора были «эсхатологическим испугом» [26, с. 98], внезапно увидели государственную власть, лишившейся своей сакральной легитимности, а официальную Церковь - уклонившейся в ересь. По словам современного старообрядческого историка Д.А. Урушева, «Московское царство, Третий Рим, вселенское хранилище православной веры обернулось мрачным Вторым Вавилоном» [27]. На эту грандиозную метаморфозу старообрядцы ответили чередой восстаний и бунтов (например, Соловецким сидением (1668-1676), Хованщиной (1682) и бегством в отдаленные регионы: Среднюю Азию, Закавказье, Сибирь, Дальний Восток, Северную Америку, Османскую империю. В их мировоззрении произошли серьезные трансформации, вызванные тем, что обновленная Церковь вытеснила их из своего организма, а государство объявило вне закона. Наиболее радикальным старообрядческим ответом были самосожжения [28; 29].
В то же время началось конструирование старообрядчества как мировоззрения и как идеологии. Образ «древлего благочестия» из традиционного стал превращаться в религиозный. Негативной стороной этого стало отторжение «никонианства»; позитивной - идейный корпус Стоглавого собора (1551), постановившего: «Якоже предаша нам Самовидцы и слуги Бога Слова Святии Апостоли и Святии Отцы; такоже подобает и всем православным Християном рукою уставляти, и двема персты крестное знамение, на лице своем воображати и поклонятися <...>. Аще кто двема персты не благословляет, якоже и Христос, или не воображает двема персты крестнаго знамения, да будет проклят» [30, с. 76]. По определению Андриана (Четвергова), старообрядческого митрополита начала XXI века, «клятвы, наложенные на старый обряд и на постановления “Стоглава”, были приговором русской старине, православной древности» [31, с. 21].

По некоторым подсчетам, в «старую веру» ушла примерно 1/5 часть населения России [32, с. 2]. Спасаясь от «зимы еретической», пассионарная часть русского народа отделилась от остальной его части и устремилась в строительство своего идеального Социального. По мнению Н.И. Костомарова, «в нашей истории раскол был едва ли не единственным явлением, когда русский народ не в отдельных личностях, а в целых массах, без руководства и побуждения со стороны власти или лиц, стоящих на степени высшей по образованию, показал своеобразную деятельность в области мысли и убеждения. Раскол был крупным явлением народного умственного прогресса <...> раскол расшевелил спавший мозг русского человека» [33, с. 462].

Появились старообрядческие мученики, исповедники, пророки, обличители, давшие примеры сопротивления «никоновым новинам» и государству, примеры собственно старообрядческой агиографии [34; 35]. Произошло мировоззренческое и литургическое отделение староверов от «никониан», «новообрядцев». Начиная с этого времени, уже допустимо использовать термины «древлеправославные», «староверы», «старообрядцы». Однако сами староверы эти термины практически не использовали [36]. Самоназвание староверов - «православные христиане», все прочие - «еретики» (то есть не православные, чужие).

\section{Становление старообрядческой идеологии}

После осознания староверами наступления модерна как принципиально иной духовной ступени, «зимы еретической», началось становление староверческих согласий на основе новой, пессимистической эсхатологии (позднее превратившейся в экклесиологию у беспоповцев). Если после «книжной справы» Никона старообрядцы ощущали себя отличными от тех, кто остался в модернизированной греко-российской Церкви (но не противостоящими им), то после 1667 года начинается переход от старообрядчества как традиционного духовного уклада к старообрядчеству как идеологии, авторами которой являются архимандр. Спиридон Потемкин (†1664), инок Авраамий (†1672), 
прот. Аввакум Кондратьев (1620-1682), диакон Феодор Иванов (†1682), инок Епифаний (†1682), прот. Никита Добрынин-Пустосвят (†1682), свящ. Лазарь (†1682), иеродиакон Игнатий Соловецкий (†1687). По мере усиления гонений, по мере углубления географической и смысловой разобщенности староверов начинается переход от старообрядческой идеологии (идеологии бунта и возвращения) к построению конфессиональных рамок, декларирующих отличие староверов от нововеров и внутренней дифференциации в самом староверии.

В философском отношении старообрядческая идеология, несмотря на традиционалистический посыл, во многих существенных пунктах была модернистской. Н.И. Костомаров писал: «Мы не согласимся с мнением, распространенным у нас издавна и сделавшимся, так сказать, ходячим: будто раскол есть старая Русь. Нет; раскол - явление новое, чуждое старой Руси» ${ }^{1}$.

Новаторство этой идеологии проявилось, во-первых, в ее персонализме - личность автора стала занимать центральное место в старообрядческом идейном корпусе. Традиционная православная философия и литература (византийская и в особенности российская) не знала столь сильного выпячивания автора (страстотерпца, свидетеля, исповедника), каковое было означено Аввакумом $[38$, c. $24 ; 39$, с. $555 ; 40]$ и почти всеми основателями старообрядческих согласий XVIII века. Кроме личности автора, всегда обращается внимание и на личность адресата - также новая черта, отсутствовавшая в традиционном холизме древних текстов, в которых человек присутствовал лишь намеком. Важное значение имеет и описание обстановки, контекста, вынудившего автора к определенному умонастроению («Житие» Аввакума лучшая тому иллюстрация).

Во-вторых, в этой философии первое место занимает логика, казуистика и манипулятивные приемы полемики, а не преемственность смыслов. Создание поля убедительности в полемике староверов между собой и с новообрядческими миссионерами было самой важной методической деталью. Именно в поисках компетентности на этом поле, к примеру, братья Денисовы-Мышецкие изучали древнегреческую и европейскую философию [41, с. 207].

В-третьих, новаторством была и настойчивая апелляция к чуду, к которому Отцы Церкви всегда относились осторожно. Автобиографическое «Житие» Аввакума и прочие старообрядческие тексты преисполнены описаниями мистических доказательств правильности старой веры: заново отрастают вырванные языки, отрубленные руки сами складывают двуперстие, обидчики «ревнителей» немедленно падают замертво. Старообрядческие проповедники, начиная с Аввакума, подчеркивали важность озарений, видений, в которых им открылась апокалиптическая природа никоновских нововведений [7, с. 413-417]. И эти «чудесные свидетельства» вдруг переламывают русский средневековый скептицизм. Дело не в истинности/надуманности таких свидетельств, а в их месте. Традиционное

\footnotetext{
${ }^{1}$ Цит. по: [37, с. 353].
}

святоотеческое богословие использовало такие примеры редко, опасаясь нездоровой экзальтации. В произведениях первых староверов чудо - проявление болезненной интуиции наступившей десакрализации, разрыва между старорусской повседневной святостью и нововременными реалиями. Чудо здесь служит спасительным мостом, воссоединяющим оторвавшийся здешний мир с миром святого. «Чудесные» свидетельства о неимоверной выносливости под пытками и готовности вновь на эти пытки отважиться - черты староверия, бывшие привлекательными для множества неофитов [42, с. 132]. «Чудесные» свидетельства как знак неотмирности, функционирования по законам инобытия - черты, только сегодня официально заявленные как элементы новопротестантской «облегченной» духовности (см.: [43]) и практикующиеся уже большинством современных новообрядцев. Староверы были первооткрывателями постмодернистской харизматической духовности. Задолго до постмодерна они интуитивно опирались на один из его основных инструментов - на переворачивание модерна в «безумие». Так, отбиваясь от рационализма модерна, старообрядцы стали основываться на элементах православия, никогда не бывших главными: мученичество и чудо.

В-четвертых, сами староверы неоднократно подчеркивали факт свершившейся десакрализации - в этом пункте они радикальнее мистиков господствующей Церкви. Экстремум этой философии - беспоповское учение о «приточном» (от «притча»), или «духовном» антихристе $[44$, c. $28 ; 45$, c. 19], а также учение о разделении горнего и дольнего (антихристов Вавилона против Небесного Иерусалима) [46, с. 21].

Так стал образовываться конструкт старообрядческого мировоззрения и старообрядческой идеологии. В его основе лежит признание объективности мировой десакрализации, вступившей в предельную фазу дезонтологизации бытия, уничтожения самих условий для осуществления Традиции. Это отсутствие условий вынудило старообрядческих богословов перейти на предложенное им новообрядцами (светской культурой, новообрядчество взрастившей) мировоззренческое, логико-полемическое поле.

\section{Анафемы гонителей и анафемы гонителям: генезис негативной идентичности}

По словам А.Г. Дугина, «раскол для русской истории есть точка перехода от Традиции к религии, от сакральной традиции к религиозной редуцированной форме. Именно эту редуцированную форму Православия, от которой отсечено сакральное, староверы и называют уничижительно “никонианством"» [47, с. 117]. Самым первым жестом модерна в расколе было даже не взаимное анафематствование и заявление о своей позиции как полноте Истины (такое в церковной практике - постоянное явление), но непрестанное наращивание барьеров между собой и идейным противником. Выпадение из традиционного русско-православного «побратимства» [48, с. 212] означало выпадение во внешний холод и мрак, сообщение с 
которым (даже из миссионерских побуждений) чревато собственным необратимым остыванием.

Первые проклятия на старые обряды были оглашены Никоном 24 февраля 1656 года в Успенском соборе Московского Кремля, подтверждены же они были в присутствии иностранных иерархов на Большом Соборе 1666-1667 годов. Сторонники старого чина не только отлучались от Церкви, но объявлялись государственными преступниками [49, с. 71]. Староверы не остались равнодушными к отлучениям, наложенным на них. Они не приняли проклятий, так как, согласно их воззрениям, анафемы были произнесены не иерархами Церкви, но еретиками $[50$, с. 6] - не старообрядцев отлучили от Церкви, напротив, новообрядцы откололи себя от полноты Священного Писания, представителями которого остались староверы [51, с. 116]. В этом пункте видно расщепление традиционной православной экклесиологии: для новообрядцев Церковь - организация, для старообрядцев сообщество, хранящее Предание [52, с. 305]. Лидеры староверов из тюрем сами отлучили новообрядцев - во главе с Никоном - от Церкви, объявляли Никона антихристом [53; 54]. Бытие двух версий православия в России началось с обоюдных проклятий. Еще Аввакум подчеркивал основу для принятия священства от новообрядцев: «Аще он поп, проклинает никониян и службу их, и всею крепостию любит старину, по нужде, настоящаго ради времени да будет поп» [55, с. 221].

Здесь важно отметить эсхатологические параметры негативной идентичности. Анафемы, официально провозглашенные новообрядцами на старые обряды и на придерживающихся их, были первой серьезной бороздой между старо- и новообрядчеством. До 1666 года большинство староверов воспринимало раскол как временную смуту. Но анафема - это размежевание принципов и духовностей. Поскольку двух Церквей (как Тела Христова) существовать не может, то Истина может быть либо у старо-, либо у новообрядцев. Староверы восприняли анафемы не как отлучение старообрядцев от Церкви, но как хулу на все Вселенское Православие [56]. Если бы анафемы были наложены не на старые обряды, а на старообрядцев как смутьянов и раскольников, это воспринималось бы как действие дисциплинарного характера [57]. Но был проклят сам духовный проект. Анафемы были произнесены на догматическом уровне, что также характеризует непонимание анафематорами иерархичности форм богослужения. В Церкви всегда присутствовал определенный плюрализм в отношении внешних форм богопочитания, если только эти внешние формы не затрагивали догматического содержания.

Вопрос о границе Церкви переместился с таких компонентов церковности, как наличие иерархии и верность учению Соборов и Отцов, в поле исключительно внешней области вероисповедания, воспринимаемой только символически, а впоследствии - и юридически. До конца XIX века староверы даже не именовались православными из-за неподчинения синодальной администрации [58; 59, с. 15]. Традиция сократилась до своих изъявительных форм - такая динамика была задана именно новообрядцами в момент официального отлучения. И староверы этой динамике подчинились - стали воспринимать «отлучивших» их новообрядцев как самоотлученцев от Церкви, ужавшейся до сообщества, верного древнему образу богопочитания [60]. Так осуществился некий смысловой консенсус, знаменовавший отход от традиционной духовности в религиозную (идеологическую).

При всем том неверно думать, что старообрядчество есть лишь реакция на радикализм реформ Никона, традиционалистический взрыв, последовавший после осуществления литургических нововведений. Староверие, как и изначальное «никонианство», есть две формы (схожие в своих крайностях) единой реакции неприятия Нового времени; традиционалистический проект старообрядцев был таким же противосовременным, как и клерикальный проект Никона, опиравшийся на опыт контрреформационной активности католиков и западно-русских православных. «Никонианство» себя как проект не реализовало, состыковавшись с государством и будучи вынужденным транслировать государственническую идеологию, отчего внутренний контрсекуляризм новообрядцев неуклонно стремился к минимуму и не мог сопротивляться наступлению антидуховности модерна в национальном масштабе. Новообрядческое православие, постепенно ослабляя свою связь с Традицией, вытеснилось в идеологическую сферу. Старообрядчество, полемизируя с противоположной версией православия, также было вынуждено к переходу из традиционного в религиозно-идеологическое семантическое пространство, сочетавшее противониконианский и противогосударственнический элементы.

В эти печальные времена разорвалась надвое прежде единая православная экклесиология и сотериология. Староверы и новообрядцы поставили в основание своих идеологий отдельные элементы древнего учения о спасении. Так, для старообрядцев до сих пор спасение - это методика, для новообрядцев - принадлежность к Церкви-организму (см.: [61, с. 67; 26, с. 96]). Каждый их этих элементов, взятый в отдельности, привел к существенным социальным и мировоззренческим искажениям. Так на руинах Святой Руси возникли «две России» (см.: [62, с. 215-221]). Вместо соревнующихся проектов теперь, в представлении староверов, победившие новообрядцы (сращенные с государством в построении нового образа жизни) виделись «клеветниками», созидателями и отпрысками «псевдоРоссии», «псевдоЦеркви». По мнению А.Г. Дугина, «после 1666 года существует не одна Россия, а две - официальная прозападная, системная, и донная, старообрядческая, восставшая на зло и отступничество, истинная Русь. Аввакума и Морозовой. Двуперстная Русь. Христова. Исусова. Две страны - две церкви, две нации» [63].

Анафематствование было важным фактором в формировании не только старообрядческой экклесиологии более того, в формировании самого стиля староверческой идентичности - самообнаружении «от противного».

Зазор, обозначенный между двумя версиями православия, одна из которых обвинялась в раскольничестве, 
другая - в отступничестве, с годами продолжал шириться. Возник своеобразный старообрядческий пафос. Еще Аввакум заявлял в письме к Тишайшему: «Видишь ли, самодержавне? Ты владеешь на свободе одною русскою землею, а мне Сын Божий покорил за мое темничное сидение и небо, и землю»². Такое позиционирование служило ментальным щитом, предохранявшим как старообрядцев от прикосновения к чуждой и опасной чувственности барокко, так и для новообрядцев, опасающихся перехода наиболее ревнительской своей части в староверие. Для этого противостарообрядческие полемисты постоянно подчеркивали «гордыню», «суемудрие», «буесловие» «раскольников». Причин для «совращения в раскол» было достаточно не только для грамотных христиан, недовольных имперским цезаропапизмом и популяризацией католических и протестантских элементов в XVIII веке. Были и социальные факторы: прежде всего, старообрядческая ученость, родившаяся как реакция, но вскоре создавшая собственные школы полемики, книжности, богословия [65]. И.С. Аксаков отмечал: «Крестьяне, одаренные духовными талантами <...> большей частью обращаются в раскол, предоставляющий им широкое поле деятельности. Они бегут к раскольникам, в леса и пустыни, где находят особого рода общества людей ученых, то есть начитанных, обширные библиотеки, читателей, издателей, переписчиков и все пособия для свободного общения мысли и слова» [66, с. 636].

В качестве иллюстрации Иван Аксаков приводил также строки из староверческого духовного стиха [66, с. 637]:

Не могу пребыть без рыдания!..

До конца тлеет благочестие;

Процветает ныне все нечестие:

Духовный закон с корения ссечен,

Чин священническ сребром весь пленен,

Закон градской в конец истреблен.

Вместо законов водворилось беззаконие,

Лихоимцы вси грады содержат.

Немилосердые в градах первые,

На местах злые приставники!

Дух антихристов возвея на нас...

Не могу пребыть без рыдания!..

Для старообрядца христианство было не результатом личного выбора, но повседневным послушанием Христу и Священному Преданию через осуществление литургико-морального кодекса: «И служба продолжительнее, и пение умилительнее, и чтение истовее, и украшение богаче, и стояние благоговейнее, и чистота тщательнее, и вся молитва внимательнее» [67, с. 592].

Эта черта старообрядческой идеологии породила и мощную старообрядческую агиографию, причем не лубочно-барочную типа «Четьих-Миней» Димитрия Ростовского, но народную, тесно связанную с традиционными нерукотворными инстанциями Крови и Почвы. Епископ Андрей (Ухтомский), создавший впоследствии особый вариант единоверия, писал: «За старообрядчеством осталась <...>

\footnotetext{
${ }^{2}$ Цит. по: [64, с. 301]
}

церковная дисциплина и церковная благовоспитанность, а среди новообрядцев, как их печальная привилегия, стали развиваться религиозное разгильдяйство, нравственная распущенность и общая беспринципность. Старообрядцы защищали для себя свободу церковной жизни, и по существу своему они были подлинными республиканцами с великолепным идеалом библейской теократии. Это были народные защитники народной культуры. Новообрядцы по существу своему были всегда лишь безобрядниками, преклоняясь только перед внешним блеском полицейской государственности, они в глубине души были только рабами и лакеями всякой власти, лишь бы она согласилась их кормить» $[68$, с. 255].

Известный расколовед Н.И. Ивановский, говоря о причинах привлекательности староверия, на первое место ставил ревность старообрядцев к молитве и в качестве правила (скрепляющего повседневность), и в качестве способа непрестанной связи со священным (что и является сущностью Традиции) [69]. Молитвенное правило (ритуал) в староверии является обязанностью, пронизывающей все стороны повседневности: «Молитися по уставу церковному неотрочно, и неотложно, на кийждо день, каков местно и можно» [70, с. 97].

Владимир Соловьев писал, что единственной причиной, препятствующей переходу половины русских в староверие, является лишь боязнь уголовных преследований [71, с. 19] - столь действенным был отгородительный щит, созданный анафемами.

Тем не менее, традиционные бытийственные основания новообрядческих «низов» не позволяли сделать эту дистанцию абсолютной. Это иллюстрируется как принципиальным тезисом поповцев о наличии священнической благодати даже в падшем «никонианском» сообществе, так и фактическим установлением единоверия в официальной Церкви (еще до придания ему миссионерского статуса).

Максимума эта дистанция достигла только в наши дни, когда на руины уничтоженной в советское время традиционной бытийственности наслоилась постмодернистская виртуальная ментальность, ищущая самовыражения в субкультурном обособлении и сектантском дистанцировании. Поэтому лишь в 2007 году староверы-поповцы решились на то, на что не решались (в явном виде) все время своего существования - на официальное объявление новообрядчества ересью [72]. Конечно, были пробы соборного осуждения (соборы беглопоповцев 1832 и 1846 гг.), сложилась и практика принятия новообрядцев (погружательно крещеных) через отрицание «новообрядческой ереси». Но объявление Освященным собором РПСЦ в 2007 году новообрядчества «ересью второго чина» - это ультрановаторское событие в истории взаимоотношения старо- и новообрядчества [73].

Принятый в 2007 году «Чин отречения от ересей», в котором новообрядчество подробно и неоднократно уравнивается с еретическими сообществами, вызвал критику, показывающую опасение некоторых старообрядцев относительно превращения древлеправославия из традиционного упования в идеологическую религию: 
«Нам достались не “единственно спасительные" обряды и уставы - но нам досталась непрерывная живая традиция православного благочестия в поместной русской форме, хоть и не изначальной, но находящейся в органическом естественном развитии. Это - большое богатство, по сравнению хотя бы с теми же новообрядцами, у которых традиция была неоднократно подорвана насилием, произволом и воздействием факторов, совершенно нецерковных по своей природе. Наша Церковь, Божией милостью, сохранялась до сих пор от рабствования текущим интересам государственной власти, от внутренней бюрократизации, она в значительной мере сохранила такую исконную христианскую черту как общинность. Наша Церковь имеет объективную возможность быть народной и живой Церковью - без демагогического опошления этих хороших слов. И эта Церковь не выдумана мечтателями, а исконно существует, реально сохраняет апостольскую преемственность вероучения и иерархии» [74].

В этих словах хорошо показаны оба вектора старообрядчества: традиционность и идеологичность, тяготеющая к преодолению традиционности и пострелигиозному переводу старообрядчества в субкультуру, начало чему было положено в интеллектуальной и социально-политической деятельности, развившейся в тени взаимных проклятий.

Возникнув как исключительно реакционное, контрсекулярное духовное движение, старообрядчество вынужденно перешло за новообрядчеством из формата традиционного духовного движения в формат религии, которому свойственны идеологический догматизм, политическая либо социальная ангажированность, рационализм, административная структуризация. Тем не менее, до второй половины XX века старообрядчество оставалось преимущественно традиционным в силу сохраненных естественного образа жизни, старинной социальной структуры и непрерывности обращенности к своим древнерусским и древнехристианским истокам. Когда из-под староверия была выбита традиционная социальная и экономическая основа, оно стало виртуализоваться, стремительно превращаясь в стилизационную пострелигию. И в этом превращении, длящемся ныне, были задействованы те ментальные и интеллектуальные техники, которые в свое время придали староверию его контрсекулярный, традиционалистический характер.

\section{Список литературы}

1. Пудалов Б.М. К литературной истории сборника «Измарагд»: формирование 2-й («Основной») редакции // Труды отдела древнерусской литературы. Т. 55 / ред. Л.В. Соколова. СПб.: Дмитрий Буланин, 2004.

2. Каптерев Н.Ф. Патриарх Никон и его противники в деле исправления церковных обрядов. - Сергиев Посад: Изд-во М.С. Елова, 1913.

3. Белокуров С.А. Сильвестр Медведев об исправлении богослужебных книг при патриархах Никоне и Иоакиме // Христианское чтение. - 1885. - № 11, 12.

4. Крылов Г., прот. Как Агиасма стала «скачущей» (история одного литургического разночтения) [Электронный ресурс]. - Режим доступа: http://www.bogoslov.ru/ text/2308475.html

5. Кутузов Б.П. Церковная «реформа» XVII века как идеологическая диверсия и национальная катастрофа. - Барнаул: Изд-во ФПСХППБ РПСЦ, 2008.

6. Пентковский А.М. Об особенностях некоторых подходов к реформированию богослужения // Православное богословие на пороге третьего тысячелетия: Материалы Богословской конференции Русской Православной Церкви (Москва, 7-9 февраля 2000 г.). - М., 2000.

7. Юрганов А.Л. Категории русской средневековой культуры. - М.: МИРОС, 1998.

8. Сазонова Н.И. Изменение богослужебного текста как направление трансформации религиозного сознания: на материале литургической реформы патриарха Никона: автореф. дис. ... д-ра филос. наук. - Томск: ТомГПУ, 2009.

9. Каптерев Н.Ф. Патриарх Никон и царь Алексей Михайлович. В 2 т. Т. 1. - М.: Изд-во Спасо-Преображенского Валаамского монастыря, 1996.

10. Опарина T.A. «Исправление веры греков» в Русской Церкви первой половины XVII века [Электронный ресурс]. — Режим доступа: http://krotov.info/history/17/2/oparina_2.htm

11. Успенский Б.А. История русского литературного языка (XIXVII вв.). - М.: Аспект Пресс, 2002.

12. Успенский Н.Д. Коллизия двух богословий в исправлении русских богослужебных книг в XVII веке // Богословские труды. Вып. 13. - М.: Изд-во Московской Патриархии, 1975.

13. Сове Б.И. Проблема исправления богослужебных книг в России в XIX-XX веках // Богословские труды. Вып. 5. М.: Изд-во Московской Патриархии, 1970.

14. Макарий, митр. Московский. Введение в православное богословие. - Минск: Харвест; М.: АСТ, 2000.

15. Демкова Н.С. Житие протопопа Аввакума (творческая история произведения). - Л.: ЛГУ, 1974.

16. Генон Р. Царство количества и знамения времени // Р. Генон. Кризис современного мира. - М.: Эксмо, 2008.

17. Каптерев Н.Ф. Патриарх Никон и царь Алексей Михайлович. В 2 т. Т. 2. - М.: Изд-во Спасо-Преображенского Валаамского монастыря, 1996.

18. Андрей (Ухтомский). История моего старообрядчества // М.Л. Зеленогорский. Жизнь и труды архиепископа Андрея (князя Ухтомского). - М.: Мосты культуры, 2011.

19. Деяния Великого Московского собора 1666/1667 года / Святая Русь: Интернет-журнал Истинно-Православной Церкви России [б/м, 2008] [Электронный ресурс]. - Режим доступа: http://holyrussia.narod.ru/Sobor_1666_67.html

20. Кутузов Б.П. Тайная миссия патриарха Никона. - М.: Алгоритм, 2007.

21. Мельников Ф.Е. История Русской Церкви (со времен царствования Алексея Михайловича до разгрома Соловецкого монастыря). - Барнаул: Изд-во ФПСХППБ РПСЦ, 2006.

22. Полознев Д.Ф. Московские патриархи Иоасаф II, Питирим, Иоаким и Адриан / Седмица.Ru [M., 2008-2013] [Электронный ресурс]. - Режим доступа: http://www.sedmitza.ru/ text/436206.html

23. Правила о низложении Патриарха Никона с патриаршаго престола // Историческое исследование дела Патриарха Никона / сост. Н. Гиббенет. Часть вторая. - СПб.: Изд-во МВД, 1884.

24. Каптерев Н.Ф. Суждение большого московского собора 1667 года о власти царской и патриаршей // Богословский вестник. - 1892. - Т. 3. - № 8.

25. Анисимов Е.А. Дыба и кнут: политический сыск и русское общество в XVIII веке. - М.: Наука, 1999. 
26. Флоровский Г.В. Пути русского богословия. - М.: Институт русской цивилизации, 2009.

27. Урушев Д.А. Под знаком зверя. Церковный раскол XVII века обернулся величайшей религиозной драмой русского народа / Русская народная линия: информационно-аналитическая служба [б/м, б/г] [Электронный ресурс]. - Режим доступа: http://ruskline.ru/monitoring_smi/2007/02/10/ pod_znakom_zverya/

28. Пулькин М.В. Огненная прелюдия империи (Старообрядческие дискуссии о самосожжениях в конце XVII века) // Человек между Царством и Империей: сб. материалов междунар. конф. / ред. М.С. Киселева. - М.: Институт человека $\mathrm{PAH}, 2003$.

29. Пругавин А.С. Самоистребление. Проявления аскетизма и фанатизма в расколе // Русская мысль. - 1885. - № 1, 2.

30. Стоглав. Собор, бывший в Москве при великом государе царе и великом князе Иване Васильевиче (в лето 7059). London: Trübner \& $C^{\circ}$, Paternoster Row, 1860.

31. Андриан, еп. Казанско-Вятский. Старообрядчество как часть общенациональной культуры // Старообрядчество как историко-культурный феномен: Материалы МНПК. Гомель: Изд-во ГГУ, 2003.

32. Андреев И.Л. Великий Раскол: истоки и смысл // Преподавание истории и обществознания в школе. - 2001. — № 6.

33. Костомаров Н.И. Исторические монографии и исследования. Т. 12. История раскола у раскольников. - СПб.: Изд-во Д.Е. Кожанчикова, 1872.

34. Семененко-Басин И.В. Канонизации святых в старообрядческих церквах России // Религиоведение. - 2008. - № 3.

35. Урушев Д.А. Епископ Павел Коломенский в старообрядческой литературе первой половины XVIII века // Религиоведение. - 2010. — № 1.

36. Мингалев В.В. «Черные» мифы о старообрядчестве / Самарское староверие [Самара, 2013] [Электронный ресурс]. - Режим доступа: http://samstar-biblio.ucoz.ru/ publ/145-1-0-589

37. Плеханов Г.В. Раскол как одно из выражений общественной мысли // Г.В. Плеханов. Сочинения. Т. ХХ. - М.; Л.: Госиздат, 1925.

38. Гудзий Н.К. Протопоп Аввакум как писатель и как культурноисторическое явление // Житие протопопа Аввакума, им самим написанное, и другие его сочинения. - М., 1934.

39. Зеньковский С.А. Русское старообрядчество / ред. В.В. Нехотин. - М.: Ин-т ДИ-ДИК; Квадрига, 2009.

40. Пушкарев С.Г. Историография старообрядчества // Журнал Московской Патриархии. - 1998. - № 7.

41. Лаппо-Данилевский А.С. История русской общественной мысли и культуры XVII-XVIII вв. - М.: Наука, 1990.

42. Бычков В.В. 2000 лет христианской культуры sub specie aesthetica. В 2 т. Т. 2. Славянский мир. Древняя Русь. Россия. - М.; СПб.: Университетская книга, 1999.

43. Caputo J.D. Apostles of the Impossible: On God and the Gift in Derrida and Marion // God, the Gift, and Postmodernism / ed. Caputo J.D., M.J. Scanlon. - Bloomington: Indiana University Press, 1999.

44. Кожурин К.Я. Краткий катихизис. - СПб.: Невоград, 2006.

45. Пичугин Л.Ф. 0 таинственных трех с половиною годах царства антихриста. - М.: Археодоксія, 2009.

46. Гурьянова Н.С. Эсхатологическое учение староверов и мессианское царство // Гуманитарные науки в Сибири. 2000. — № 2.

47. Дугин А.Г. Философия традиционализма. - М.: АрктогеяЦентр, 2002.
48. Смирнов И.П. Мегаистория. К исторической типологии культуры. - М.: Аграф, 2000.

49. Гейден А. Из истории возникновения раскола при патриархе Никоне. - СПб.: Изд-во А.С. Суворина, 1886.

50. Нагевичене В.Я. Церковный раскол и старообрядчество. Челябинск: Изд-во ЮУрГУ, 2010.

51. Усов И.Г. Церковь Христова временно без епископа. - Новосибирск: Слово, 2008.

52. Дугин А.Г. Метафизика Благой Вести // А.Г. Дугин. Абсолютная Родина. - М.: Арктогея-Центр, 1999.

53. Бубнов Н.Ю. Старообрядческое «антижитие» патриарха Никона // Святые и святыни северорусских земель. - Каргополь, 2002.

54. Штейнгольд А.В. Историко-этимологический комментарий к выбранным местам из старообрядческого антижития патриарха Никона // Русские староверы за рубежом. Труды по русской и славянской филологии. Лингвистика. Новая серия. IV / ред. И.П. Кюльмоя. - Тарту: Изд-во Тартуского ун-та, 2000.

55. Аввакум, прот. Послание рабам Христовым // Материалы по истории раскола за первое время его существования. Т. 5. Историко- и догматико-полемические сочинения первых расколоучителей. Ч. 2. Сочинения бывшего юрьевецкого протопопа Аввакума Петрова / ред. Н.И. Субботин. - М.: Изд-во Э. Лисснера и Ю. Романа, 1879.

56. Андриан, еп. Казанско-Вятский. Право славьте // Остров Веры. - 2002. - № 7.

57. Михайлова Н.М. 0 старообрядческом расколе / Москва - Третий Рим [б/м], 2009-2011 [Электронный ресурс]. - Режим доступа: http://www.3rm.info/17115-ostaroobryadcheskom-raskole-natalya-mixajlova.html

58. Беседы о существенных свойствах Церкви Христовой и о том, что старообрядцы всех согласий не составляют Св. Соборной и Апостольской Церкви (из бесед миссионеров гор. Боровска). - М.: Изд-во Братства Пафнутия Боровского, 1888.

59. Ивановский Н.И. Обличение раскола старообрядства. Тобольск: Изд-во Епарх. Братства св. Димитрия Солунского, 1895.

60. Симеон (Дурасов), священноинок. Размышления об анафемах / Крылья голубиные [б/м, б/г] [Электронный ресурс]. - Режим доступа: http://posad.1gb.ru/default. aspx?ti $=1 \& h t i=50$

61. Флоренский П., свящ. Философия культа (Опыт православной антроподицеи). - М.: Мысль, 2004.

62. Дугин А.Г. Социология геополитических процессов в России. - М.: Евразийское Движение, 2010.

63. Дугин А.Г. Старообрядчество и русская национальная идея / Радио Духовный Антихрист. М., [б/г] [Электронный ресурс]. - Режим доступа: http://staroverie.ru/idea.shtml

64. Зеньковский С.А. Учение отцов Пустозерских // Патриарх Никон. Протопоп Аввакум: сборник / сост. В.А. Десятников. - М.: Новатор, 1997.

65. Пругавин А.С. Запросы и проявления умственной жизни в расколе // Русская Мысль. - 1884. — № 1.

66. Аксаков И.С. Краткие записи о странниках или бегунах // Русский архив. - 1866. - № 4.

67. Раскол в приходе с. Георгиевского, что при р. Лухе Юрьевецкого уезда // Костромские епархиальные ведомости. 1892. — № 22.

68. Андрей (кн. Ухтомский), еп. 10 писем о старообрядчестве // М.Л. Зеленогорский. Жизнь и труды архиепископа Андрея (князя Ухтомского). - М.: Мосты культуры, 2011. 
69. Ивановский Н.И. Причины устойчивости раскола // Н.И. Ивановский. Собр. соч. Т. 1. - Казань: Изд-во Казан. императ. ун-та, 1898.

70. Ковылин И.А. Чин оглашения входящим в православную веру // Сборник для истории старообрядчества / сост. Н.И. Попов. - М.: Изд-во Каткова и Кํ, 1864.

71. Соловьев В.С. Русская идея. - Брюссель: Жизнь с Богом, 1987.

72. Постановления Освященного Собора Русской Православной Церкви (состоявшегося в граде Москве 16-19 октября 2007 г. Н. ст.) / Русская Православная Старообрядческая Церковь: Официальный сайт Московской митрополии. М., 2012 [Электронный ресурс]. - Режим доступа: http://rpsc.ru/documents/postanovleniya-coborov/ postanovleniya-osvyaschennogo-sobora-russkoy-pravoslavnoystaroobryadcheskoy-tserkvi-sostoyavshegosya-v-grade-moskve2007-goda

73. Езеров А.В., Шишкин А.В. Хроника Освященного Собора РПСЦ 2007 года глазами его делегатов / Современное Древлеправославие. М., 1998-2013 [Электронный ресурс]. Режим доступа: http://www.staroobrad.ru/modules.php?na me $=$ News2\&file $=$ article\&sid $=232$

74. Симеон (Дурасов), священноинок. Рассмотрение нового проекта «Чина присоединения к древлеистинной (старообрядческой) Русской Церкви приходящих от никонианской ереси» / Крылья голубиные [б/м, б/г] [Электронный ресурс]. - Режим доступа: http://posad.1gb.ru/default. aspx?ti=1\&hti $=87$

УДК 7.01/04(47+57)

ББК 85.0

\section{С.В. ИВАНОВА}

\section{МЕТАМОРФОЗЫ РОССИЙСКОЙ ТРАДИЦИИ ИКОНОГРАФИИ ВОСКРЕСЕНИЯ}

Рассматривается изменение иконописной традиции в иконографии Воскресения в России XVIII века. Исследуется новый тип иконографии, который появляется в это время, и делается вывод о его несомненной связи с гравюрами нидерландских Библий и циклом иллюстраций к Апостольскому символу веры. В связи с этим начинает переосмысляться древний православный образ Воскресения. Ключевые слова: иконография Воскресения, Пасха, иконы Воскресение, Сошествие во ад, Библия Пискатора, «Библия в лицах», Апостольский символ веры, Воскресение «полного извода».

B пасхальной иконографии в России на рубеже XVII века появляются те изменения, которые трудно объяснить как закономерное развитие прежней традиции. Византийская икона Пасхи - «Воскресение»,

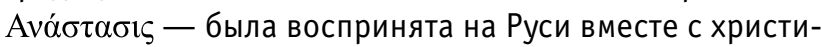
анством. Иконография Воскресения в последующие века свидетельствует о том, что русским иконописцам были известны все новые композиционные типы этого образа, появлявшиеся в Византии. И хотя на Руси создавались и самобытные композиционные решения, их основная идея не отличалась от идеи византийского образа, проникнутого светом и торжеством победы, они в полной мере отражают святоотеческое учение о Воскресении.

Однако в конце XVI - начале XVII веков в России появляется совершенно новая икона, также надписанная «Воскресение», но объединяющая два разных сюжета, с-поразительным соотношением частей. 0браз, который можно было бы отождествить с православной иконой Воскресения, расположен внизу, а над ним оказывается западноевропейское «Восстание от Гроба», до того времени еще неизвестное на Руси. Эта композиция требует внимательного анализа и специального комментария.
Понять происхождение подобного произведения, исходя из логики представленных изображений, невозможно. Можно лишь предположить наличие у иконописца стремления совместить два образа (православный и католический), а также представить Воскресение не только в его абсолютном значении - в традиции православной иконографии, но и в земном плане - как в образе «Восстание от Гроба», широко распространенном в Западной Европе.

Примером такого совмещения может послужить византийская икона XIV века из Македонии: на ней в нижнем регистре изображены жены-мироносицы у гроба (земной план), а в верхнем регистре - сам образ Воскресения (Анастасис). Однако на новой иконе, напротив, земное возвышается над небесным - то есть явно совершается нечто иное.

Что могло повлиять на столь странное решение? Почему тот праздничный образ, который до сих пор почитали отдельно, объединяется с новым, прежде неизвестным в России? Почему образ, который традиционно располагался вверху ${ }^{1}$, вдруг оказывается в нижней части иконы?

\footnotetext{
${ }^{1}$ См., напр., схемы расположения сюжетов в каппадокийских храмax IX-XI веков и фотографии фресок [1]. Напомним расположение
} 